\title{
Strategies of Accessible City for Malaysia as A Developing Country
}

\author{
Nur Amirah Abd Samad 1,2, Ismail Said 1, Asiah Abdul Rahim ${ }^{3}$ \\ ${ }^{1}$ Faculty of Built Environment and Survey, UTM, 81310 Skudai, Malaysia. \\ 2 Department of Architecture and Built Environment, Faculty of Engineering and Built Environment, UKM. \\ ${ }^{3}$ Department of Architecture, Kulliyyah of Architecture and Environmental Design, IIUM. \\ nuramirahabdsamad@gmail.com, ismailbinsaid@gmail.com, arasiah@iium.edu.my \\ Tel No. of *corresponding author: 012-2315857
}

\begin{abstract}
Becoming an Accessible City in developing countries has mitigating barriers as compared to developed countries. It is comprehensive to nondiscriminate PwDs in access and facilities for equal opportunity. Accessibility legislation of different nations has various success in implementing and enforcing Universal Design through regulatory, government initiatives, and planning approaches. ASEAN developing nations have awareness and advocacy, because the fragmentary built environment, resulting in Accessible City concept that has not strived to expectation. Eliciting from interviews of access consultants and city planning regulations from London, Oslo, and Singapore. Conclusively, extraction of inclusion strategies is to be adapted for implementation in Malaysia.
\end{abstract}

Keywords: Accessible City; Universal Design; Inclusion strategies; developing countries.

eISSN: 2398-42870 2021. The Authors. Published for AMER ABRA cE-Bs by e-International Publishing House, Ltd., UK. This is an open access article under the CC BYNC-ND license (http://creativecommons.org/licenses/by-nc-nd/4.0). Peer-review under responsibility of AMER (Association of Malaysian Environment-Behaviour Researchers), ABRA (Association of Behavioural Researchers on Asians/Africans/Arabians) and CE-Bs (Centre for Environment-Behaviour Studies), Faculty of Architecture, Planning \& Surveying, Universiti Teknologi MARA, Malaysia.

DOI: https://doi.org/10.21834/ebpj.v6iSI4\%20(Special\%20lssue\%204).2913

\subsection{Introduction}

Proceeds of the International Decade of Disabled Person 1983 to 1992, the conferment of the Americans with Disabilities Act (ADA) was realized in the United States in 1990. It was acknowledged worldwide as a recognizable legal framework in protecting PwDs rights from discrimination in various aspects (Kose, 2011). Emphasized by Kose (2011), the ADA movement accelerated the Japanese government to introduce some accessibility measures at the national level and find ways to integrate new trends toward accessibility into their policy initiatives by enacting the Japanese with Disability Act in 1993. In the United Kingdom, coined by Clarkson et al. (2015), the incorporation of the Disability Discrimination Act (DDA) in 1995 as a rights-based legislative measure focuses on access to services in achieving social inclusion for PwDs.

With the member states of UN signing the Standard Rules on the Equalization of Opportunities for Persons with Disabilities in 1993, it was made into the Scandinavian region's agenda for accessibility and political action plans. Additional to the UN Standard Rules and influenced by EU legislation, Scandinavian countries also signed and adopted the United Nation Convention on the Rights of Persons with Disabilities in 2006 which eminently impact the concept of Design for All in Europe (Bendixen, 2010; Strand, 2014).

Advocacy for PwDs rights issue within the Asia Pacific region, as highlighted by Nur Amirah et al. (2018b) is under the UNESCAP where Malaysia and ASEAN countries have signed the proclamation of the Asian and Pacific Decade of Disabled Persons since its $1^{\text {st }}$ decade in 1993-2002. When the UNCRPD and its Optional Protocol was embraced in 2006, Malaysia has committed to promote and

eISSN: 2398-42870 2021. The Authors. Published for AMER ABRA CE-Bs by e-International Publishing House, Ltd., UK. This is an open access article under the CC BYNC-ND license (http://creativecommons.org/licenses/by-nc-nd/4.0/). Peer-review under responsibility of AMER (Association of Malaysian Environment-Behaviour Researchers), ABRA (Association of Behavioural Researchers on Asians/Africans/Arabians) and CE-Bs (Centre for Environment-Behaviour Studies), Faculty of Architecture, Planning \& Surveying, Universiti Teknologi MARA, Malaysia.

DOI: https://doi.org/10.21834/ebpj.v6iSI4\%20(Special\%20lssue\%204).29 
protect PwDs rights by the enactment of the Persons with Disabilities Act 2008, formulating policies, taking appropriate measures and resolve preliminary issues to ratify the treaty into the Malaysian domestic legal framework (Tah et al., 2016).

\subsection{Issues and Problem}

Apparently, the issues and problem identified emerged from prominent developed and developing countries at various parts of the world concerning human rights pledge of PwDs to be socially inclusive and gain equal access to the built environment. Malaysia is currently in the enhanced public awareness phase towards equal rights for PwDs in all aspect, as stated in the UNCRPD. Public awareness about PwDs and their rights to access public facilities, public transport and services has improved throughout this three-decade. It was a slow pace in the awareness process, giving implementation stagnancy for about 20 years since the establishments of Malaysian Standards in 1990. Asiah et al. (2014) depicted that Malaysia's scenario was that after independence in 1957, the country was rebuilding and was developing its economy, infrastructure, education, and other necessities. Consequently, throughout the 1960s, 1970s and the 1980s, the government are still focusing on developing the economy in urban and rural areas. Thus, the MS establishment in 1990, demonstrated that the government has started addressing the PwDs needs, especially within the built environment in the late 1980s.

As stipulated by several local researchers (Hussein et al., 2012; Kadir et al., 2012; Kamarudin et al., 2012; Mohd Isa et al., 2016) the MS1183:1990; MS1184:1991 and MS1331:1993, consecutively, are the code of practice for fire precautions, access to buildings and access outside buildings for PwDs. Evidence of awareness and technical knowledge of providing accessibility for PwDs is the obligatory responsibility of using MS code of practice stated above, in detailed design for PwDs design requirements. Making it legally bound to be an enforced law, (Asiah et al., 2015a; Hussein et al., 2012; Maidin, 2012; Yusof et al., 2016) all posits that the provision of by-law 34A in the Uniform Building By-Laws (UBBL) is mandatory for all new public buildings to be accessible for PwDs with the compliance to MS1184 requirements.

As the known initiation of the UNCRPD in 2006, it was timely and essential for enacting the Persons with Disabilities Act in 2008. A government committed to adopting a more inclusive policy and legislation action in recognition of PwDs to contribute to social wellbeing, social diversity and economic development in the community and the society. However, the PwDs Act 2008 has gaps where there is non-remedial nature of the act that makes it non-enforceable in certain conditions as Malaysia has made reservations on certain Optional protocol UNCRPD articles (Tah, 2013) lack of comprehensive monitoring mechanism against violation towards PwDs; and lack of specific anti-discrimination provisions (Abdullah et al., 2017).

\subsection{Aim and Objectives of the Study}

This study aims to lay out the strategies in hopes of envisioning a developing country such as Malaysia to be an Accessible City. This can be achieved through the implementation of regulatory, government initiatives, and planning approach. The objectives have been detailed out as follows; (i) to explore available and potential implementation of government initiates accessibility planning in multiple identified case study cities; (ii) to strategize on inclusive city planning and implication for an accessible city that can be adapted to suit the local context of a developing country.

\subsection{Literature Review}

\subsection{Accessibility and Universal Design (UD) from Global and Regional Perspectives}

Many researchers of Disability Studies indicated that disability issues apparently had arisen a global perspective shift when it comes to the PwDs human rights movement. PwDs are seen as the social minorities and have been discriminated in probably in all areas, including the right to access buildings and transportation facilities; and denied education, employment, and housing. As a result of their medical condition and its perception, has adjudicates the societies' social attitudes of the stereotypical image about PwDs capabilities. As society perception still lingers on social oppression towards minorities that regards PwDs to always receiving charity and often discriminated.

Stein et al. (2010) emphasize that the UNCRPD is the first human rights treaty of the 21st century and the first UN's legally enforceable instrument, specifically empowering PwDs rights. They further claim that the drawbacks of prior international laws lack in legally binding characters. Furthermore, as Bickenbach (2014) and Quinlivan (2012) expressed, the UNCRPD is based on the social model of disability, focusing on how societal constraints seek to limit the full inclusion of PwDs in society. This indicates that society is disabling people through perceived norms. The social model recognizes that society can remove disabling barriers as society's responsibility and not the disabled individual. Quinlivan (2012) and Stein et al. (2010) also emphasized that the social model of disability underpins the entire UNCRPD which adopts a rights-based approach to inclusion, a paradigm shift from the traditional medical and charity-based model of disability. Hence, the social model of disability in UNCRPD covers human rights treaty obligations and addresses some non-binding resolutions. Consequently, the concerns obligations are to empower PwDs inclusion in the built environment and equal participation within the public community.

In the EU countries, including the United Kingdom and the Republic of Ireland, the comprehensive enforceable access laws enable independent living and safety and accessibility (Clarkson et al., 2015; Strand, 2014). Comparative studies on disability legislation conducted by the United Nation Development Programme shows that only 45 countries worldwide have anti-discrimination and other disability-specific laws. However, as for Malaysia, anti-discrimination legislation has not adhered as it would deem controversial as Malaysia and most Asian countries have multi-racial, multi-ethnic, and multi-religion community.

It is essentially known that all ASEAN countries are members of the UNESCAP and have ratified the Proclamation of the Asian and Pacific Decade of Disabled Persons for three decades currently. To expedite the implementation, an action plan had been set out in 
September 2003, the Biwako Millenium Framework (BMF) for Action Towards an Inclusive, Barrier-Free and Right Based Society for PwDs in Asia and the Pacific. As for the next Proclamation decade of 2013-2022, the UNESCAP Commission imperatively adopt the strategic framework of general principles and obligation stipulated in UNCRPD as it was established in 2006. As part of the UNCRPD, the commission adopts the Incheon Strategy to 'Make the Right Real' for PwDs in Asia and the Pacific, to catalyze action for acceleration, during the current Asian and Pacific Decade of PwDs 2013-2022 (Asiah et al., 2015b; Incheon Strategy et al., 2018).

The UNESCAP have taken the initiatives to improve the quality of life of the PwDs, and governments have already started preparing the code of practice and standards for providing facilities. However, many ASEAN countries are not able to fulfil those requirements for many other reasons (Asiah et al., 2015b) and this shortcoming is a result of the inadequate comprehensive disability law that mandates non-discrimination principle in many other countries in the Asia and the Pacific region too (Perlin, 2012). Hence, the concerns also affect the enactment of non-discrimination laws in Malaysia.

\subsection{Universal Design (UD) and Accessible Terminology}

Universal Design essentially introduced in 1985 by Ronald Mace, a disabled architect, who defines UD as a 'design of products and environments usable by all people to the greatest extent possible, without the need for adaptation design' where it applies to all ages, personal abilities and sizes, with an inclusive capability that goes beyond barrier-free and accessible design. This concept has been accepted in various design fields, such as architecture, engineering, product design, and landscape design (Erkilic, 2011; Lid et al., 2015). An enhance interpretation by Dalton (2016) states that UD encompasses nature and the environment to benefit from accessibility, safety and usability without discrimination to enable a wider cohort of people.

Likewise, in Europe, the approach is Design for All that defines 'the design for human diversity, social inclusion, and equality.' The practise of Design for All makes conscious use of the analysis of human needs, aspirations and requires the involvement of end-users at every stage in the design process (Grangaard, 2016; Harrison et al., 2015). Asian countries are likely to be influenced by the United States, so Accessible Design was more broadly used as a more positive term than Barrier-Free Design; nonetheless, it is basically linked to legislated requirements (Fletcher, 2016). Thus, these concepts are considered similar to Universal Design, which significantly recognized in architecture through architectural regulations.

Defining accessibility is that the quality of a built environment can be accessed by people with physical disabilities or the elderly. In parallel but contrasting, the term barrier-free design is a design concept to make a built environment accessible to people with physical disabilities or older people by removing the architectural barriers present in existing buildings (Sanford, 2016). The UD concept advances more comprehensively as it has the Seven (7) Principles of UD which characterize usable design solutions of products and environments, making this concept is more likely to be embraced worldwide including Malaysia and the Asian region as noted by local researchers (Kadir et al., 2013; Nur Amirah et al., 2018b; Yusof et al., 2016). Nevertheless, this holistic and innovative approach constitutes a creative and ethical challenge for all planners, designers, entrepreneurs, administrators, and political leaders.

\subsection{Methodology}

This study compares the establishment of UD concept and application in particular countries on accessibility. The methodology is a qualitative method that will be a participatory worldview and narrative design (Creswell et al., 2018). The qualitative research design selected is content analysis and focus group interview with a case studies research design approach for the multiple developed and developing countries identified globally (Groat et al., 2013). The selection of the case studies focuses on two aspects that is, (i) the effective implementation of an accessible environment and; (ii) the concept of Universal Design, its ideology and interpretation within local context and governance. The procedure involves good rapport with local government authorities from these identified accessible and inclusive cities. The identified and acknowledged access cities of London, Oslo and Singapore, where the researchers manage to obtained official presentations of their inclusive city planning and its documentation and keep the limitation of study focuses on the legislative aspect on enhancing accessibility and building regulation only.

\subsection{Findings and Discussion}

\subsection{The Accessible City and Inclusion Strategies}

It is noted that developed countries have laid out strategies for inclusion and accessibilities in their cities. There are measures that they have initiated with their leaders, for example in Norway where 'The government wants to shy away from thinking in which the individual is defined as the problem and in which special measures for people with disabilities are the main solution.' As this motion was from the top-down of the leadership ladder, making implementation more effectively enforced (Lund, 2016; Nohr et al., 2016). In London, they also strive to make London accessible starting in 2012 for the London Paralympic Games that gave them a significant push to achieve inclusivity and accessibility within their built environment at the stadium and surrounding areas. The concept of Inclusive Design means designing and creating places that everyone can enjoy confidently and independently with choice and dignity (Inclusive Design Standards, 2013).

The findings derive from reviews of literature and expert interview from case study countries as follows in table 1:

Table 1. Comparative Inclusion Strategies of Developing Countries 


\begin{tabular}{|c|c|c|c|c|}
\hline $\begin{array}{l}\text { Inclusion } \\
\text { Strategies }\end{array}$ & City of London & City of Oslo & City of Singapore & $\begin{array}{l}\text { Malaysian Urban Cities } \\
\text { (Developing Country) }\end{array}$ \\
\hline $\begin{array}{l}\text { Accessibility } \\
\text { Mission \& Vision }\end{array}$ & $\begin{array}{l}\text { 'My } 2020 \text { Vision sets out what } \\
\text { is needed for London to } \\
\text { remain the best city in the } \\
\text { world. I also want London to } \\
\text { be the most accessible city in } \\
\text { the world. We have shown } \\
\text { what we can do in the } \\
\text { Olympic Park, and we can } \\
\text { use that experience to ensure } \\
\text { that all new development in } \\
\text { London maintains this high } \\
\text { level of accessibility to help } \\
\text { change perceptions of } \\
\text { disability and enabling } \\
\text { disabled people to be part of } \\
\text { our economy and fully } \\
\text { contribute to our great city.' } \\
\text { Mayor of London, } 2014\end{array}$ & $\begin{array}{l}\text { 'Action plan for Universal } \\
\text { Design and increased } \\
\text { accessibility, the government } \\
\text { is bringing both the equality } \\
\text { policy and sustainability policy } \\
\text { an important step further. UD } \\
\text { is an expression of a value put } \\
\text { on equality by society to } \\
\text { provide better equal } \\
\text { surroundings for PwDs. UD } \\
\text { also contributes to social and } \\
\text { economic sustainability as part } \\
\text { of the national sustainability } \\
\text { strategy.' } \\
\text { Norwegian Ministry of Children } \\
\text { and Equality }\end{array}$ & $\begin{array}{l}\text { 'As users of friendly built environments, } \\
\text { we have special needs that are } \\
\text { dependent on age and different physical } \\
\text { abilities. This portal aims to create } \\
\text { awareness of friendly built environments, } \\
\text { the key to making Singapore an all- } \\
\text { inclusive and barrier-free society.' } \\
\text { https://friendlybuildings.bca.gov.sg/ }\end{array}$ & $\begin{array}{c}\text { 'Putrajaya, as a city where residents, workers } \\
\text { and visitors of all ages, especially the elderly } \\
\text { and the disabled, can live without barriers and } \\
\text { can enjoy the same opportunities and life } \\
\text { chances as others.' } \\
\text { Putrajaya Corporation }\end{array}$ \\
\hline $\begin{array}{l}\text { Terminology \& } \\
\text { Concept }\end{array}$ & $\begin{array}{l}\text { - Accessibility } \\
\text { - Inclusive Design }\end{array}$ & $\begin{array}{l}\text { - Accessibility } \\
\text { - Design for All } \\
\text { - Universal Design }\end{array}$ & $\begin{array}{l}\text { - Barrier-Free } \\
\text { - Accessibility } \\
\text { - Universal Design } \\
\text { - Ageing-In-Place }\end{array}$ & $\begin{array}{l}\text { - Universal Design } \\
\text { - Accessibility } \\
\text { - Barrier-Free Design }\end{array}$ \\
\hline \multirow[t]{2}{*}{$\begin{array}{l}\text { Regulator } \\
\text { Agency }\end{array}$} & \multirow[t]{2}{*}{$\begin{array}{l}\text { - Department of } \\
\text { Communities and Local } \\
\text { Government } \\
\text { - Department for Transport } \\
\text { - Mayor's Transport }\end{array}$} & \multirow[t]{2}{*}{$\begin{array}{l}\text { - Norwegian Ministry of Local } \\
\text { Government and } \\
\text { Modernization } \\
\text { - Norwegian Ministry of } \\
\text { Children and Equality }\end{array}$} & $\begin{array}{l}\text { - Ministry of Health } \\
\text { - Building and Construction Authority } \\
\text { (BCA) }\end{array}$ & $\begin{array}{l}\text { - Ministry of Women, Family and Community } \\
\text { Development (MWFCD/KPWKM) } \\
\text { - Ministry of Urban Wellbeing, Housing and } \\
\text { Local Government (KPKT) } \\
\text { - Ministry of Health }\end{array}$ \\
\hline & & & $\begin{array}{l}\text { - Land Transport Authority } \\
\text { - National Parks Board }\end{array}$ & $\begin{array}{l}\text { Future strategies: } \\
\quad \quad \text { Further to engage the Ministry of } \\
\text { Transportation (MOT) \& Ministry of } \\
\text { Tourism, Arts and Culture (MOTAC) \& } \\
\text { Department of National Heritage. }\end{array}$ \\
\hline \multirow[t]{2}{*}{$\begin{array}{l}\text { Regulatory, } \\
\text { Supplementary, } \\
\text { Supporting } \\
\text { Documents \& } \\
\text { Action }\end{array}$} & \multirow{2}{*}{$\begin{array}{l}\text { - Equality Act 2010: The } \\
\text { legal framework that protects } \\
\text { disabled people from } \\
\text { discrimination. It replaces } \\
\text { anti-discrimination legislation, } \\
\text { including the Disability } \\
\text { Discrimination Act } 1995 \\
\text { (DDA) } \\
\text { - Approved Document Part } \\
\text { M of the Building } \\
\text { Regulations 2010; Access to } \\
\text { and use of buildings, Volume } \\
2 \text { - Buildings other than } \\
\text { dwellings. } \\
\text { - Shaping Neighbourhoods } \\
\text { Accessible London: Achieving } \\
\text { an Inclusive Environment. A } \\
\text { Supplementary Planning } \\
\text { Guidance for London Plan } \\
\text { Implementation Framework. } \\
\text { - Inclusive Design Standards } \\
\text { - Access Statement and } \\
\text { Consultation with Access } \\
\text { Consultants }\end{array}$} & \multirow{2}{*}{$\begin{array}{l}\text { Community planning based } \\
\text { on Universal Design in } \\
\text { different stages through } \\
\text { national action programs } \\
\text { and plans } 1997 \text { - 2018: } \\
\text { - Planning for All 1997-2001 } \\
\text { \& Universal Design 2002- } \\
2004 \\
\text { - Universal Design as } \\
\text { Planning Principle at local } \\
\text { level 2005-2009 } \\
\text { - Universal Design as } \\
\text { national project 2009-2013, } \\
\text { 2014-2015 } \\
\text { - Municipal network for } \\
\text { Universal Design 2015 - } \\
\text { 2018, The Planning and } \\
\text { Building Act } \\
\text { - Action Plan - Norway } \\
\text { universally designed by 2025 } \\
\text { - National Transport Plan } \\
\text { 2010-2020 } \\
\text { - Mandate M420 on Universal } \\
\text { Design of buildings for public } \\
\text { procurement. } \\
\text { - Standards Norway has the } \\
\text { secretariat for the CEN BT } \\
\text { WG 213, Strategic Advisory } \\
\text { Group Accessibility (SAGA), } \\
\text { which is to implement the EU } \\
\text { Mandate M473. }\end{array}$} & \multirow{2}{*}{$\begin{array}{l}\text {-The Enabling Masterplan (2011-2016) } \\
\text { - Accessibility Master Plan (2006-2015) } \\
\text { - Action Plan for Successful Ageing } \\
\text { Building Control Regulations } \\
\text { amended in } 1989 \\
\text { - Mandate the provision of barrier-free } \\
\text { accessibility in new buildings and } \\
\text { buildings undergoing major retrofitting } \\
\text { works } \\
\text { - Code on Barrier-free Accessibility in } \\
\text { Buildings } 1990 \text { to prescribe the minimum } \\
\text { requirements for compliance } \\
\text {-Compliance and Approval of Building } \\
\text { Plans } \\
\text { - Issuance of Temporary Occupation } \\
\text { Permit or Certificate of Statutory } \\
\text { Compliance }\end{array}$} & $\begin{array}{l}\text { - Persons with Disability Act } 2008 \text { (Act } \\
\text { 685). } \\
\text { - Street, Drainage and Building Act } 1974 . \\
\text { Uniform Building (Amendments) By- } \\
\text { Laws (UBBL) 1991. By-law 34A. } \\
\text { - } \quad \text { PwDs Action Plan 2016-2022 (National) } \\
\text { - } \quad \text { MS 1184:2014, Universal Design in the } \\
\text { built environment - Code of practice } \\
\text { (Second Revision) }\end{array}$ \\
\hline & & & & $\begin{array}{l}\text { Future strategies: } \\
\text { Establish a Strategic Plan \& Structure } \\
\text { Plan ranging from } 10 \text { years to } 15 \text { years for } \\
\text { more effective implementation. } \\
\text { Also having Action Plan \& Local Plans in } \\
\text { strategic areas but with details on } \\
\text { accessibility with UD requirements and } \\
\text { needs. } \\
\text { Establish UD Guideline \& Accessibility } \\
\text { Checklist at every Local Authority. } \\
\text { Initiation of a Pre-consultation \& an } \\
\text { Accessibility Plan [during submission of } \\
\text { Development Order (DO) \& Building Plan } \\
\text { (BP)] by several Local Authorities such as } \\
\text { Putrajaya Corporation (PPj), Petaling } \\
\text { Jaya City Council (MBPJ), Kuala Lumpur } \\
\text { City Hall (DBKL) \& Seberang Perai } \\
\text { Municipal Council (MPSP). }\end{array}$ \\
\hline $\begin{array}{l}\text { Adaptive } \\
\text { Inclusion } \\
\text { Strategies \& } \\
\text { Future Action } \\
\text { Plans }\end{array}$ & $\begin{array}{l}\text { - The Approved Document } \\
\text { Part M; has listed out in detail } \\
\text { the requirements and } \\
\text { provision needed with } \\
\text { detailed drawings. } \\
\text { - Impact assessment - } \\
\text { Evaluating access statement } \\
\text { requirements in Part M of the } \\
\text { building regulations. } \\
\text { - Integrate Inclusive Design } \\
\text { Principles at every stage of } \\
\text { the Development Process } \\
\text { BS8300-2:2018. }\end{array}$ & $\begin{array}{l}\text { - Implementation of UD in the } \\
\text { Norwegian Planning } \\
\text { - Established political } \\
\text { consensus and long- } \\
\text { standing technical support } \\
\text { (white paper by Manneråk } \\
\text { national committee 2001) } \\
\text { - Municipalities and regional } \\
\text { authorities are resources } \\
\text { for achieving universal } \\
\text { societies and national } \\
\text { development goals }\end{array}$ & $\begin{array}{l}\text { To recognize developers and architects } \\
\text { for going beyond Code compliance \& } \\
\text { adopting user-centric design principles: } \\
\text { BCA Universal Design } \\
\text { Award - 2006-2012 } \\
\text { Universal Design Mark } \\
\text { Certification - 2012 } \\
\text { A More accessible built } \\
\text { environment }\end{array}$ & $\begin{array}{l}\text { Identified implementation obstacles: } \\
\text { - There are no amendments for Acts relating to } \\
\text { building architecture such as Road Transport } \\
\text { Act; Street Drainage Building Act (Only a clause } \\
\text { (34A) stating to provide access for PwDs to and } \\
\text { in building); Town and Country Planning Act } \\
\text { (Act 172) to ensure the Universal Design aspect } \\
\text { shall be enforced. } \\
\text { - There are no "Penal Code" and "Punitive } \\
\text { Clause", this raises the problem in enforcement. } \\
\text { - The Status of Malaysia's National People with } \\
\text { Disabilities Council - there are committee } \\
\text { members that are not named but referred to as } \\
\text { representative of certain government agencies. }\end{array}$ \\
\hline
\end{tabular}




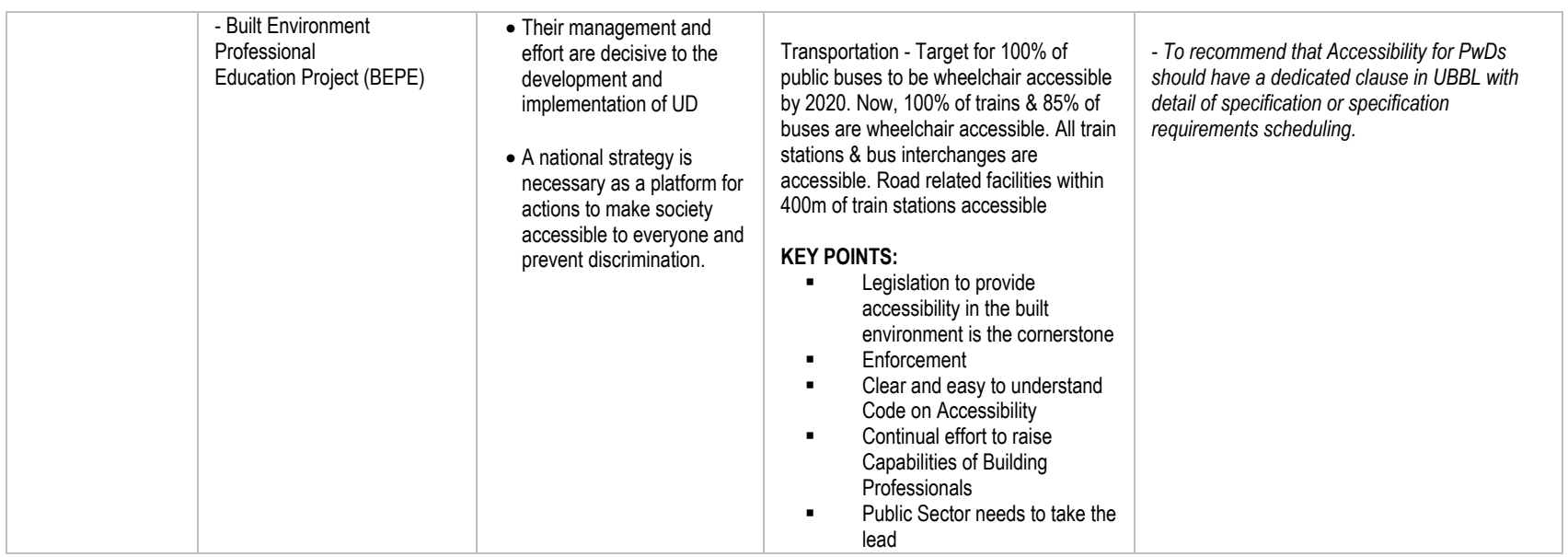

Source: Nur Amirah et al. (2018a, 2018b).

\subsection{Implication of Research for Future Planning}

\subsection{Adaptation of Inclusion Strategies for Developing Nation}

Malaysia has also shown some developments in catering to the needs of Persons with Disabilities (PwDs) yet. There is the need to efficiently implement UD in Malaysia, the need for more professionals or researchers in this area, and the need to revisit the current standards codes. Many have increasingly questioned the effectiveness of this legislation and standards with disabilities in Malaysia as unsatisfactory or ineffective in their implementation and design outcomes (Abdul Kadir et al., 2018). Previous research by (Abdullah et al., 2017; Md Tah et al., 2017; Nur Amirah et al., 2018a; Skarstad et al., 2018; Yusof et al., 2016) highlight similar issues about the indication that there is a potential gap between having legislation and ensuring their implementation. Furthermore, pointing to questions about perceptions, knowledge and the understanding of professionals in the construction industry and the role this legislation and rules, have in influencing these professionals to execute Universal Design in their design.

\subsection{Conclusion}

Significantly, Malaysia has been committed to promoting and protecting the rights of PwDs and this is manifested by enacting the Persons with Disabilities Act in 2008, formulating government policies and began taking appropriate measures to comply with UNCRPD laws and resolve preliminary issues surrounding the ratification of the treaty into Malaysian domestic legal framework. Hence, this study formulates Accessibility Implementation strategies for use under the ministry and government agencies in innovation possibilities of expanding the existing policies to enhance accessibility for more effective implementation for our public building. UD is the most relevant concept, and the general trending concept besides the terminology is recognized within all Malaysian Ministry and Government Agencies. UD provides the design needs for the PwDs and will eventually compliment all other users regardless of age and ability and can benefit all users. To further the UD concept of inclusive to innovative, instead of oppressing creativity for architects, planners, and designers, it pushes them to be inventive

\section{References}

Abdul Kadir, S., \& Jamaludin, M. (2018). Sustainable Life and Social Development through Universally Designed Environment (Vol.3).https://doi.org/10.21834/ajebs.v5i17.49

Abdullah, N., Hanafi, H., \& Hamdi, N. I. M. (2017). The Rights of Persons With Disabilities in Malaysia: The Underlying Reasons for Ineffectiveness of Persons with Disabilities Act 2008. International Journal For Studies on Children, Women, Elderly and Disabled, Vol. 1 (January).

Asiah, A. R., Ismawi, Z., Nur Amirah, A. S., \& Che Raiskandar, C. R. (2014). Universal design and accessibility: Towards sustainable built environment in Malaysia. In H C. e. a. (Eds.) (Ed.), Universal Design 2014: Three Days of Creativity and Diversity. Assistive Technology Research Series (Vol. 35, pp. 299-306). IOS Press:https://doi.org/10.3233/978-1-61499-403-9-299

Asiah, A. R., Naziaty, M. Y., Nur Amirah, A. S., \& Izawati, T. (2015a). Universal Design and Social Responsibility: Towards A Sustainable Built Environment. Journal of Universal Design in the Built Environment, 1(1), 5-13.

Asiah, A. R., Nur Amirah, A. S., \& Che Raiskandar, C. R. (2015b, 2nd -3rd March 2015). Overview of Universal Design Application and Accessibility in Major Cities of ASEAN Countries. 2nd International Conference on ASEAN Community 2015, Kuala Lumpur.

endixen, K. (2010, 2nd November 2014). Perspective from Denmark: Design for All - Point of no Return! 3rd International Conference for Universal Design in Hamamatsu Japan 2010, Hamamatsu. 
Bickenbach, J. (2014, 2014/08/01). Universally design social policy: when disability disappears? Disability and Rehabilitation, 36(16), $1320-1327$. https://doi.org/10.3109/09638288.2014.932447

Clarkson, J. P., \& Coleman, R. (2015, 2015/01/01/). History of Inclusive Design in the UK. Applied Ergonomics, 46, $235-247$. https://doi.org/https://doi.org/10.1016/j.apergo.2013.03.002

Creswell, J. W., \& Creswell, J. D. (2018). Research Design: Qualitative, Quantitative and Mixed Methods Approaches (5th Edition ed.). SAGE Publication:

Dalton, C. (2016). Interaction Design in the Built Environment: Designing for the 'Universal User'. In H. Petrie, J. Darzentas, T. Walsh, D. Swallow, L. Sandoval, A. Lewis, \& C. Power (Eds.), Universal Design 2016: Learning from the Past, Designing for the Future. Studies in Health Technology and Informatics (Vol. 229, pp. 314-323). IOS Press: Amsterdam.

Erkilic, M. (2011). Conceptual Challenges Between Universal Design and Disability in Relation to the Body, Impairment, and the Environment: Where Does the Issue of Disability Stand in The Philosophy of UD? Universal Design and Disability, 2(METU JFA ), 181-203. https://doi.org/DOI: 10.4305/METU.JFA.2011.2.9

Fletcher, V. (2016). Inclusive/universal design: People at the center of the design process. In The Routledge Companion for Architecture Design and Practice: Established and Emerging Trends (pp. 251-268). Taylor and Francis:https://doi.org/10.4324/9781315775869

Grangaard, S. (2016). Towards universal design hotels in Denmark [Conference Paper]. 3rd International Conference on Universal Design, UD $2016,229,260-262$. https://www.scopus.com/inward/record.uri?eid=2-s2.0-84988473860\&partnerlD=40\&md5=69c35b080a64ce27af3186571beceb11

Groat, L., \& Wang, D. (2013). Architectural Research Methods (2nd Edition ed.). John Wiley \& Sons:

Harrison, J., \& Dalton, C. (2015). The Familiar and the Strange: The Limits of Universal Design in the European Context. Journal of Universal Design in the Built Environment, 1(1), 49-67.

Hussein, H., \& Yaacob, N. M. (2012, 12/19/). Development of Accessible Design in Malaysia. Procedia - Social and Behavioral Sciences, 68, 121-133. https://doi.org/http://dx.doi.org/10.1016/j.sbspro.2012.12.212

United Nations Economic and Social Commission for Asia and the Pacific. (2018). Incheon Strategy: To "Make the Right Real" for Persons with Disabilities in Asia and the Pacific and Beijing Declaration including the Action Plan to Accelerate the Implementation of the Incheon Strategy(United Nations Publication).

(2013). Inclusive Design Standards(London Legacy Development Corporation).

Kadir, S. A., \& Jamaludin, M. (2012). Applicability of Malaysian Standards and Universal Design in Public Buildings in Putrajaya. Procedia - Social and Behavioral Sciences, 36, 659-669. https://doi.org/http://dx.doi.org/10.1016/j.sbspro.2012.03.072

Kadir, S. A., \& Jamaludin, M. (2013). Universal Design as a Significant Component for Sustainable Life and Social Development. Procedia - Social and Behavioral Sciences, 85, 179-190. https://doi.org/http://dx.doi.org/10.1016/j.sbspro.2013.08.349

Kamarudin, H., Hashim, A. E., Mahmood, M., Ariff, N. R. M., \& Ismail, W. Z. W. (2012, //). The Implementation of the Malaysian Standard Code of Practice on Access for Disabled Persons by Local Authority. Procedia - Social and Behavioral Sciences, 50, 442-451. https://doi.org/http://dx.doi.org/10.1016/j.sbspro.2012.08.048

Kose, S. (2011). The Impact of Aging on Japanese Accessibility Standards In W. F. E. Preiser \& K. H. Smith (Eds.), Universal Design Handbook (2nd ed.). McGraw-Hill Education:https://books.google.com.my/books?id=riLXHAO9Zt4C

Lid, I. M., \& Solvang, P. K. (2015, Apr-Jun). (Dis)ability and the experience of accessibility in the urban environment [Conference Paper]. Alter-European Journal of Disability Research, 10(2), 181-194. https://doi.org/10.1016/j.alter.2015.11.003

Lund, E. (2016). Local and Regional Authorities as Resources for Implementing Universal Design Policy in Norway. In H. Petrie, J. Darzentas, T. Walsh, D. Swallow, L. Sandoval, A. Lewis, \& C. Power (Eds.), Universal Design 2016: Learning from the Past, Designing for the Future. Studies in Health Technology and Informatics (Vol. 229, pp. 63-68). IOS Press: Amsterdam.

Maidin, A. J. (2012). Legal Framework Regulating for Improving Accessibility to Built Environment for Disabled Persons in Malaysia. https://ssrn.com/abstract=1992205

Md Tah, I. H., \& Mokhtar, K. A. (2017, 01/01). Transforming Disability Studies through Legal Perspectives in Malaysia. 7, 51-55.

Mohd Isa, H., Zainol, H., Alauddin, K., \& Hafizuddin Nawi, M. (2016). Provisions of Disabled Facilities at The Malaysian Public Transport Stations (Vol. 66).https://doi.org/10.1051/matecconf/20166600016

Nohr, T., \& Langset, E. K. (2016). Inclusive Planning: Paramount in Today's Norway. In H. Petrie, J. Darzentas, T. Walsh, D. Swallow, L. Sandoval, A. Lewis, \& C. Power (Eds.), Universal Design 2016: Learning from the Past, Designing for the Future. Studies in Health Technology and Informatics (Vol. 229, pp. 199-210). IOS Press: Amsterdam.

Nur Amirah, A. S., Ismail, S., \& Asiah, A. R. (2018a). Planning Accessibility Strategies and Connectivity for Malaysian Urban Built Environment. In G. Craddock, C. Doran, L. McNutt, \& D. Rice (Eds.), Transforming our World Through Design, Diversity and Education. Studies in Health Technology and Informatics (Vol. 256). IOS Press: Netherlands. https://doi.org/10.3233/978-1-61499-923-2-367

Nur Amirah, A. S., Ismail, S., \& Asiah, A. R. (2018b). A Review of Universal Design and Accessibility Legislations in Implementation Strategies Among Asian Countries. In Proceeding of The 12th SEATUC Symposium: Engineering Education and Research for Sustainable Development. Yogyakarta, Indonesia.

Perlin, M. (2012). Promoting Social Change in Asia and the Pacific: The Need for a Disability Rights Tribunal to Give Life to the UN Convention on the Rights of Persons with Disabilities. SSRN Electronic Journal. https://doi.org/DOI: 10.2139/ssrn.2002787

Quinlivan, S. (2012). The United Nations Convention on the Rights of Persons with Disabilities: an introduction. ERA Forum 2012, 13, 71-85. https://doi.org/DOI $10.1007 / \mathrm{s} 12027-012-0252-1$ 
Sanford, J. A. (2016). Design for all users. In Community Wayfinding: Pathways to Understanding (pp. 81-101). Springer International Publishing:https://doi.org/10.1007/978-3-319-31072-5_5

Skarstad, K., \& Randolph, S. (2018). Disability-inclusive development assistance policies --the cases of Norway and Australia.https://doi.org/10.13140/RG.2.2.20638.43848

Stein, M., \& Lord, J. E. (2010). Monitoring the Convention on the Rights of Persons with Disabilities: innovations, lost opportunities, and future potential. . Human Rights Quarterly, 32(3), 689-728.

Strand, V. B. (2014, 2014/01/02). Norway's Ratification of the UN Convention on the Rights of Persons with Disabilities: Highlighting Current Discourses in the Field of Human Rights in Norway. Nordic Journal of Human Rights, 32(1), 75-83. https://doi.org/10.1080/18918131.2013.878894

Tah, I. H. M. (2013, December 2 - 3, 2013). A Need for Remedial Provision to Protect Persons with Disabilities in Malaysia. Proceeding - Kuala Lumpur International Business, Economics and Law Conference. Hotel Putra, Kuala Lumpur, Malaysia.978-967-11350-2-0.

Tah, I. H. M., \& Mokhtar, K. A. (2016). Malaysia's Ratification of the UN Convention on the Rights of Persons with Disabilities (UN CRPD). International Journal of Business, Economics and Law, Vol 11(Issue 4 (Dec)).

Yusof, L., \& Jones, D. (2016). The Application of Universal Design Legislation and Standards in Malaysia and Australia. Journal of Universal Design in the Built Environment, 2(1), 17-35. 